\title{
Criminalidade juvenil $e$ estratégias de (des)confinamento na cidade
}

\section{Youth criminality and sentencing strategies \\ in the city}

\section{esumo}

A problematização apresentada neste trabalho integra um projeto transdisciplinar de pesquisa, cujo ponto de partida é a preocupação das comunidades com a criminalidade. A cidade de São Leopoldo município com 200 mil habitantes, situado na Região Metropolitana da capital do estado do Rio Grande do Sul - é tomada como referência na análise da cultura do medo relacionada ao jovem infrator. Os dados do município apontam os maiores indicadores na região, que apresenta a maior taxa de internação de adolescentes e a menor proporção de aplicação de medidas em meio aberto. Tais fatores, aliados à escassa cobertura de acompanhamento dessas medidas concorrem para colocar estes jovens em permanente risco, o que leva os autores à discussão dos conceitos de vulnerabilidade e inclusão social. Propõese que um dos enfrentamentos necessários em meio aberto é o imaginário social, onde a adolescência pobre e infratora se define como um tipo peculiar de figura-limite, resultante da dificuldade de distinguir entre pertencimento e inclusão, entre o que está fora e o que está dentro, entre exceção e norma.

Palavras-chave: violência juvenil, cidade, inclusão.

\section{Carmen S. de Oliveira}

Psicóloga.

Doutora em Psicologia Clínica pela PUCSP.

Professora da Universidade do Vale do Rio dos Sinos - Unisinos.

\section{Maria Palma Wolff}

The problem presented in this paper is an integral part of a transdisciplinary research project that analyzes the concerns of communities with criminality. The municipality of São Leopoldo is used as a reference in the analysis of the culture of fear related to young offenders. The municipal data reveals that the city has the highest rate of imprisonment of adolescents and the lowest proportion of non custodial measures in the region. These factors, in combination with a lack of information about these methods, place these youngsters in permanent risk of incarceration. In this light, the paper discusses the concepts of vulnerability and social inclusion. It proposes that one of the challenges to non custodial measures is that of social image, in which the poor offending adolescent is defined as a specific type of marginal figure, as a result of the difficulty in distinguishing between belonging and inclusion, between those within and those on the outside, between the exception and the norm.

Key words: juvenile violence, urban, inclusion.

\section{Assistente Social.}

Doutora em Direitos Humanos e Liberdades Fundamentais pela Univ. de Zaragoza - Espanha.

Professora da Unisinos.

\section{Rongldo Henn}

Jornalista.

Doutor em Comunicação e Semiótica pela PUCSP.

Professor do PPG em Comunicação da Unisinos.

\section{Marta Conte}

Psicóloga.

Doutora em Psicologia Clínica pela PUCSP.

Professora da Unisinos.

Trabalho decorrente da pesquisa transdisciplinar "Criminalidade e (trans)mutações na cidade", em desenvolvimento na Universidado do Vale do Rio dos Sinos - Unisinos, RS. 
$n$ a contemporaneidade, cada vez mais as cidades se tornam cosmopolitas enquanto trânsito de distintos personagens, em um entrelaçamento de trajetórias, diferentes formas de fruição e apropriação dos cenários e de suas interfaces. Todavia, a preocupação com a criminalidade concorre para a distância social, especialmente quando se fortalece o discurso de seu incremento como uma tendência fora de controle.

No presente texto, problematizamos as reações na cidade diante da violência juvenil. Seriam os adolescentes "bodes expiatórios" da violência urbana? Como as comunidades interpretam as finalidades das instituições socioeducativas? Que implicações se fazem presentes no cumprimento de medidas judiciais em meio aberto? Que estratégias de (des)confinamento destes jovens emergem na cidade contemporânea?

Para esta discussão é tomado como referência de análise o município de São Leopoldo, na Região Metropolitana de Porto Alegre, através de uma pesquisa transdisciplinar que faz uso de recursos quantitativos (levantamentos de dados junto ao sistema socioeducativo) e qualitativos (grupos de discussão com adolescentes em cumprimento de medidas).

Num primeiro momento, pretende-se cartografar a relação adolescente-cidade e, em especial, a inserção da juventude pobre. A seguir, são discutidas as implicações destes cenários para o acompanhamento de jovens infratores em meio aberto, discutindo conceitos como vulnerabilidade e inclusão social.

\section{Os adolescentes "trancados de fora"}

Em recente texto, Rassial (2004) refere uma seqüência do filme $O$ ódio, em que um dos jovens de periferia perde o trem para o centro da cidade e diz: "Merda, nós estamos trancados de fora". A expressão enuncia algo desses adolescentes na contemporaneidade: eles se vêem projetados em um espaço infinito, muito embora colocados de fora, fechados numa exterioridade. Curiosamente, Castel (2004) refere que hoje as duas situações principais de exclusão envolvem o desempregado de longa duração e os jovens de periferia, associando estes últimos a uma condição que também é definida pela "exterioridade completa", ou seja, caracterizada por "andanças sempre recomeçadas", "nomadismo imóvel", "deslocamento sem rumo", "agitação sem objeto".

Ao mesmo tempo em que a mobilidade parece marcante para as novas gerações, são recorrentes imagens que atestam os obstáculos deste segmento juvenil em seu enfrentamento das diferenças de oportunidades na cidade. De um lado, temos os adolescentes provenientes de regiões que concentram os maiores benefícios e têm acesso aos bens e signos valorizados socialmente.
Sua imagem é projetada como ideal social, para crianças ou adultos, como sugere Calligaris (2000), dando-lhes uma visibilidade extrema no espaço urbano. Em outras condições, contudo, encontram-se os jovens que habitam áreas que concentram as maiores carências e não atendem aos critérios mínimos de inclusão social. Estes são alijados de sua própria imagem na mídia ou por ela desqualificados diante de uma estética juvenil globalizada (DIÓGENES, 1998). Vistos como potencialmente não-consumidores, os jovens empobrecidos são hoje sequer considerados exército de mão-de-obra em um mercado de trabalho cada vez mais restrito e exigente.

Em São Leopoldo, cidade de porte médio na região metropolitana da capital do estado do Rio Grande d Sul, a população duplicou em apenas duas décadas e apresenta uma taxa de urbanização de 99\%. Por sua vez, o nível de desemprego atinge 18\% (FUNDAÇÃO DE ECONOMIA E ESTATÍSTICA, 2003), sendo que na faixa de 14 a 17 anos cerca de $45 \%$ dos adolescentes se encontram fora do mercado de trabalho:

Falta emprego, faltam cursos. Isto aqui é uma roça e um fim de mundo. Isto aqui parece cidade de interior, não tem fábrica, não tem nada. Não se ouve carro ou moto anunciando vagas como em Novo Hamburgo. Acham que o cara é mula. Eu tava trabalhando frio. Procurei quase um mês aqui. No SINE nunca tem nada, só consegui firma em Novo Hamburgo. Lá tem trabalho dentro de metalúrgica, ou de servente de obras, em madeireira e se ganha 15 a 20 por dial.

Tal contexto é agravado pelo fato de que no Brasil temos um grande contingente de jovens, o grupo mais numeroso da pirâmide demográfica (IBGE, 2001), para quem são destinadas precárias políticas públicas em um cenário de acentuadas desigualdades sociais e vivendo uma dupla rejeição, como no caso de nosso país em que se combina preconceitos de classe e raça.

Para estes jovens habitantes sem proteção, radicalmente vulneráveis, torna-se insustentável exigir tolerância ao sacrifício e reiterada renúncia diante da desapropriação material e da destituição simbólica a que se encontram expostos e expectantes. Isto porque a própria capacidade de espera e obediência contrastam, sobremaneira, com os apelos de uma sociedade de mercado hedonista e permissiva. Portanto, não é de surpreender a associação que estes adolescentes fazem entre trabalho e condição penosa:

Meu tio me convidou uma vez pra trabalhar, não só uma vez, mas era muito pouco, 5 pila, 10 pila por semana e às veiz até por mês. Eu via todo mundo arrumado, todo mundo com dinheirinho, 
desse jeito eu nunca vô chegá lá, ganhando 5 pila, 10 pila. Desse jeito nunca vô ganhá.

É assim que atitudes ressentidas se tornam comuns entre eles, que encaram seus pais como desvalidos e até otários, diante de um pai-Estado considerado tirano e injusto. Sem crédito e desacreditados por conta de uma dívida impossível de pagar devido aos imperativos de gozo consumista que os torna faltantes natos, tais segmentos juvenis precarizados acabam não sendo considerados como pertencentes à cidade, mas clandestinos e posseiros, como sugere este depoimento:

No centro, na lancheria Donatello, não vai pessoal de vila, vai os rico. Eu vou para essa lancheria, não me misturo com o embolamento. A maioria vai pro Bistrô, em frente à Caixa Econômica. Ai andam malandrinho, paninho tri, calça larga. 'Tu mora aonde?', ficam te marcando, de fita, malandro por malandro, de vila com vila, Paim x Vila Maria, Feitoria x Vila Maria. Já no Factory rola pirataria, tem civil desfarçado, de campana, segurança, boy metidinho, tudo cu de ferro que fica nas costa dos pai.

É neste contexto que se pode compreender a sedução pelo delito:

Eu tinha minha familia, eu tinha um irmão que cometia delito, arma e droga em cima da mesa e dinheiro fácil, entrando e saindo, sabe? E eu sempre via ele escondendo as armas e o carro roubado entrando na garagem. Isso me deixava muito eufórico pra um dia chegá e também fazer isso.

A partir disto, pode-se analisar melhor o mal-estar em relação à violência juvenil. Propomos que o temor e a rejeição a eles relacionados não se devam apenas por que estão em conflito com a lei, mas porque através da prática delitiva denunciam, de certa forma, a crise de valores na contemporaneidade, em que estamos todos à mercê de um modelo societário predatório. Trancados de fora, atestam a nova face da desigualdade que é o esgotamento das possibilidades de mobilidade social para a maioria da população. $\mathrm{O}$ ato infracional expõe, assim, o fracasso separatista da cidade, ao mesmo tempo em que constitui estratégia de não rendição a este alijamento que lhes é imposto. Eles rompem o contrato social não apenas por infringirem a lei, mas porque negam a postura de resignação e desistência diante da ameaça de exclusão.

Com isto, estabelece-se uma recusa recíproca de integração, entre estes adolescentes e a sociedade (OLIVEIRA, 2001). Ou uma "inclusão às avessas", como sugere Diógenes (1998), na medida em que, através do delito, o adolescente suburbano obtém, de certa forma, o status e a renda almejados:

O dinheiro vem fácil, não faz força nenhuma. É fácil: mete um revólver na cara de uma pessoa e toma o que tem dela, não faz força nenhuma...

Todavia, é notório que seus corpos se tornam ainda mais indesejados na cidade, pois são deslocados de uma posição de potencialmente perigosos a "inimigos número um da ordem pública". Tal estigma permite, no mínimo, delimitar o alvo de uma cultura generalizada do medo: a juventude pobre em conflito com a lei. Mas também se alimenta um circuito de ressentimento, reforçado pela desconfiança em relação ao poder público e que faz emergir o desejo de vingança, como vemos nas demandas punitivas crescentes, pelo rebaixamento da idade penal, mais policiamento, penas mais severas etc.

Colocada desta forma a argumentação, poderíamos pensar que bastaria garantir o acesso aos direitos básicos aos setores desfiliados da população, como no caso da juventude pobre, para que a mobilidade social fosse garantida, diminuindo o fosso entre as classes. Mas será que tudo se resumiria a uma questão de exclusão-inclusão?

\section{0 confinamento a céu aberto}

Como vimos até aqui, emergem, no cenário urbano contemporâneo, demandas não correspondidas por corpos zelados e seguros, em distintos grupos sociais. Aliás, esta é uma das hipóteses centrais de Bauman (2004) acerca do mal-estar identificado por Freud no nascente século XX: a liberdade é sacrificada em nome da segurança, em um contexto de enfrentamento das ameaças do frágil corpo, dos agressivos vizinhos, do mundo em movimento.

$\mathrm{O}$ autor sugere que $\mathrm{O}$ texto freudiano é um "livro de reclamações dos 
ricos", pois enquanto a insatisfação das elites era traduzida como neuroses individuais, a recusa das massas em dar livre curso a suas inclinações era considerada caso para a lei e a ordem; não se tratava de uma tarefa de psicanalistas, mas de polícia. Ou seja, o arranjo moderno e capitalista de convívio humano tinha duas faces: uma emancipatória e a outra coercitiva, cada uma voltada para um setor diferente da sociedade.

Contudo, a chamada revolução industrial necessitou do desenraizamento dos pobres, levados às fábricas para seguir novas e rígidas disciplinas, em um ambiente frio e impessoal, através do regime de comando, vigilância e punição. Ou seja, a modernidade foi uma era em que não se acreditou na emergência espontânea da ordem: esta deveria ser projetada e mantida por manejo cotidiano, o que fixava todos, vigias e vigiados, "presos ao lugar".

Hoje, em contraste, a liberdade individual é o valor supremo e as pessoas demandam mais prazer. A retórica do capitalismo neoliberal não exige mais disciplina ou fidelidade, mas flexibilização e desregulamentação. Segundo aquele autor, os poderosos não querem ser regulados ou ter sua liberdade de movimento restrita, mas, principalmente, não estão mais interessados em regular os outros. A dominação é garantida por algo menos incômodo do que as fábricas de obediência: a incerteza dos governados sobre o próximo movimento dos governantes. O que gera insegurança e incapacidade de fazer planos. Com isto, a disciplina anda e se reproduz sozinha. Desterritorializados, os sujeitos travam uma luta no escuro e a todo momento desfocada, onde a incerteza não serve como catalisador para os sofredores, mas os divide e os separa.

Esta argumentação nos leva a ressituar o tema da cidade cindida. A mobilidade e sua ausência parecem sinalizar a "nova polarização", uma vez que liberdade veio a significar liberdade de movimento (BAUMAN, 1999). É assim que em uma dimensão espacial, no topo da hierarquia, temos as elites desfrutando de uma mobilidade e de uma condição extraterritorial, enquanto as camadas inferiores sofreriam restrições espaciais, seja pelo impedimento de acesso a locais que os outros freqüentam e desfrutam, seja pela falta de mudanças ou até pela forma mais radical de confinamento, que é a prisão.

Neste cenário, o autor refere que a densidade física da população tende a aumentar mais do que sua densidade moral, para além da capacidade de absorção da intimidade humana. Isto porque a separação espacial funciona também como proibição ou suspensão da comunicação, tendo como conseqüências a redução da visão do outro e o estancamento do intercâmbio, o que favorece com que o outro isolado seja mantido na categoria de estranho. $\mathrm{Na}$ medida em que a intimidade pessoal não mais prevalece no cotidiano e vivemos entre pessoas que não conhecemos é mais provável que se recorra à "letra fria da lei", especialmente com aqueles que não consideramos nossos pares.
Assim, a indiferença pode ser considerada o sintoma dos bem-sucedidos, que tem no auto-exílio a principal saída, pois lhes permite manter a distância o que é visto como ameaça. Sua reclusão em comunidades fortificadas bem como suas interações com pessoas e lugares virtualmente idênticos os tornam cosmopolitas seletivos, que habitam o que Bauman (2004) denomina de "bolhas socioculturais" e "abrigos nucleares pessoais", onde a separação é colocada em lugar da negociação da vida em comum. Os condomínios fechados, uma espécie de propriedade privada para uso coletivo, constituem um habitat limpo e auto-suficiente, com as pontes e o fosso dos castelos medievais sendo substituídos pelos obstáculos eletrônicos.

Teremos ghetos voluntários, como nas elites, onde é impedida a entrada de intrusos, mas os de dentro podem sair à vontade; de outro, ghetos verdadeiros, lugares dos quais os pobres não podem sair, sob pena de serem hostilizados. Para a pobreza são destinados ghetos e prisões, enquanto duas estratégias de confinamento e imobilização: as prisões são ghetos com muros e os ghetos são prisões sem muros (BAUMAN, 2004). Tais "lugares fobígenos" não podem ser tomados como fenômenos acidentais e locais, mas um estado atual do laço social (RASSIAL, 2004), em que as forças centrífugas da globalização se confrontam com movimentos insulares das comunidades.

\section{Cada vez mais fechados...}

É neste ambiente que situamos a tendência ao crescente aprisionamento juvenil em nosso país. Como a procedência dos adolescentes cumprindo medidas socioeducativas em privação de liberdade é, em $85 \%$ dos casos, de famílias de baixa renda, com até dois salários mínimos (BRASIL, 2002), isto sugere que não apenas a violência juvenil, mas a pobreza aparece como "metassujeira", favorecendo a criminalização dos problemas sociais (WACQUANT, 2001). Gera-se, então, um apartheid criminológico, como no caso brasileiro, onde o sistema penal tem tradição seletiva e hierarquizada, levando à prisionalização desproporcional e discriminatória da juventude pobre.

A prisão (considerada a forma mais radical de confinamento) vem sendo destinada predominantemente aos jovens miseráveis em um cenário de imobilidade social e, desta forma, o aprisionamento segrega e torna incomunicáveis justamente tais setores da população juvenil que não podem ser incluídos socialmente e que, ao mesmo tempo, são vistos como ameaças à ordem social. A criminalização da juventude pobre tem servido não apenas para neutralizar estes sujeitos pela expulsão forçada do convívio social, mas também para aplacar o clamor público na medida em que a escolha da prisão demonstra que "algo foi feito" (BAUMAN, 1999). 
Portanto, não é de estranhar que à medida que cresce a pobreza juvenil esta necessite ser isolada e até mesmo confinada, como se observa nas crescentes taxas de internação destes adolescentes no sistema socioeducativo. O estado do Rio Grande do Sul, por exemplo, quando da implantação em 1990 do Estatuto da Criança e do Adolescente, registrava 208 internações, índice que passou para 1020 internos no ano de 2003, o que representa um aumento de $80 \%$ apenas nos últimos quatro anos. No município de Novo Hamburgo, que sedia o Juizado Regional da Infância e Juventude do qual São Leopoldo faz parte, uma recente unidade de internação foi construída com 60 vagas, enquanto 166 jovens da região já se encontravam internos no sistema, o que demandaria, em hipótese, outros três centros socioeducativos de igual porte.

Em tais unidades, via de regra, nem se pretende um treinamento para a disciplina, tampouco para a volta ou ingresso ao mercado de trabalho:

A gente fica sem fazer nada o dia inteiro, dormindo ou vendo tevê. Escola a gente tem um pouco, nem chega a duas horas por dia. A gente volta pra casa sem saber fazer nada, só cestaria e umas coisas de argila. Mas querem que a gente viva disto?

De fato, como sugere Bauman (1999), o confinamento vem se tornando uma alternativa ao emprego, o que é ainda mais pertinente no caso da juventude, na medida em que se trata de uma parcela da população que não é necessária à produção e para quem se deseja a "prisionalização", ou seja, a franqueada absorção dos hábitos do ambiente penitenciário e o reiterado encorajamento para a imobilidade, que é a marca dos excluídos.

Se o propósito da correção prisional foi visto historicamente como tentativa de reforma moral e de normalização, com suas "fábricas de trabalho disciplinado" o que se observa hoje é um certo declínio do ideal de reabilitação, como no caso do investimento em prédios de segurança máxima no sistema socioeducativo, a exemplo da unidade construída na região, com seus altos muros, guaritas e passarelas para policiais militares fazerem a ronda, pátios lajeados para coibir o uso de drogas.

Vistos como lugares impuros, os bairros suburbanos acabam sendo duplamente depositários da "sujeira" soci- al quando são escolhidos, via de regra, para sediar a implantação de novos equipamentos prisionais, como em Novo Hamburgo onde o novo centro se encontra em terreno anteriormente destinado a um aterro sanitário, em meio a uma das favelas do município.

Como sugere Wacquant (1999), a criação de unidades prisionais se constitui em "potente instrumento de organização do território". Mas, contrariando a observação deste autor sobre a experiência americana em que as vilas das zonas rurais decadentes buscaram atrair a indústria do encarceramento, na experiência da regionalização do sistema socioeducativo no Rio Grande do Sul observou-se o contrário. No caso deste novo centro, observou-se uma forte rejeição comunitária, desencadeando debates controversos em diferentes instâncias políticas e na mídia regional ao longo de vários anos. Semelhante processo se observou em 2001, quando da criação de uma unidade de semiliberdade em São Leopoldo. Identifica-se em tais circunstâncias que, ao lado da preocupação dos cidadãos em torno da violência juvenil na cidade, predomina a secular oposição a instituições que atentem contra a "qualidade de vida" urbana (WACQUANT, 1999). Estabelece-se uma outra segregação geográfica no espaço urbano que favorece ainda mais a dissociação entre "nós" e "eles" e sedimenta estratégias excludentes da "cidade para alguns".

Por outro lado, obstáculos adicionais podem se fazer presentes em um cenário que fortalece o discurso de incremento da violência como uma tendência fora de controle, alimentando a cultura do medo (GLASSNER, 2003). Este parece ser o caso de São Leopoldo, que apresenta uma população estimada em 206.702 habitantes (IBGE, 2004) e lidera o ranking de homicídios no estado, com uma taxa de 1,29/10 mil habitantes (RIO GRANDE DO SUL, 2003); apresentando também a maior taxa de internação no sistema socioeducativo, uma vezque a área de jurisdição do Juizado Regional da Infância e da Juventude $^{2}$ tem 14,2 adolescentes privados de liberdade/100 mil habitantes ${ }^{3}$, e São Leopoldo concentra 41\% dos jovens privados de liberdade dentre as 14 Comarcas desta região.

Assim sendo, cabe indagar: quais as condições para a implantação de propostas como a regionalização das unidades de internação e municipalização das medidas em meio aberto? 


\section{Quando o meio aberto se fecha}

As considerações que foram feitas nas primeiras seções desta análise nos sugerem sérias dificuldades para que os objetivos socioeducativos sejam efetivadose em nível comunitário. Vimos que novas estratégias de confinamento "a céu aberto" podem ser visualizadas na paisagem contemporânea. Isto nos coloca distantes de uma idéia de "meio aberto", uma vez que, cada vez mais, estratégias de guetificação no espaço urbano confinam e imobilizam, fazendo com que a insegurança na cidade contemporânea não apareça mais como localizada em setores de vulnerabilidade.

Em tal contexto, propomos que é o próprio conceito de inclusão que necessita ser discutido. Um estudo clássico (CASTEL, 2004) sugere pensar a inclusão a partir de dois eixos, trabalho e sociabilidade familiar e comunitária. Quando o sujeito se encontra completamente inserido nestes dois planos temos a zona de integração; uma precariedade do trabalho e fragilidade relacional definiria uma zona de vulnerabilidade; finalmente, na zona de desvinculação o indivíduo estaria sem trabalho e em isolamento social.

Portanto, o termo vulnerabilidade associado à adolescência infratora elucidaria sobre a sua precária inserção no mundo do trabalho e sobre o enfraquecimento de suas redes de pertencimento, de suas possibilidades de informação e de comunicação entre os pares; enquanto o conceito de exclusão se aplicaria a situações em que estes adolescentes se encontrassem fora do trabalho e isolados socialmente.

Mas tanto o enfrentamento da vulnerabilidade como da exclusão parecem ser condições associadas, indiscriminadamente, aos objetivos de atenção à juventude pobre como também àqueles jovens em conflito com a lei. Exemplar disto é a falha terminológica da Lei 8.069/ 90 (ECA, 2004), no artigo 90, que ao referir entidades e programas protetivos utiliza a expressão "apoio socioeducativo em meio aberto", ou seja, a mesma denominação utilizada pela lei para designar o atendimento especializado ao adolescente infrator. Segundo Brancher (2002), estaríamos diante da dificuldade de se libertar do velho Código de Menores, em sua incapacidade de diferenciar políticas básicas das situações de atendimento ao infrator da lei penal. Ainda denota a aceitação de um pressuposto de que um determinado atendimento, quando dispensado ao jovem pobre, é considerado fator de prevenção do delito juvenil e, portanto, denominado de atendimento socioeducativo em meio aberto.

Destacamos, assim, três argumentos de Castel (2004) para ressituar o tema da inclusão do adolescente em conflito com a lei na cidade. Em primeiro lugar, o termo inclusão parece ser impreciso por supor características essencialistas que colocariam "no mesmo saco" situações tão peculiares quanto a inserção social de negros, mulheres, homossexuais, portadores de necessidades especiais etc. Por outro lado, a exclusão contemporânea não exige apenas análises pontuais, mas também novas reflexões, uma vez que é impossível hoje traçar fronteiras nítidas entre setores da população. A precarização do trabalho, por exemplo, atravessa vários segmentos sociais e desestabiliza até mesmo os ditos estáveis. Em terceiro lugar, o termo exclusão sugere que exista uma situação fora do social, em que se possa demarcar o que está in ou out. Na verdade, na análise sobre a adolescência contemporânea o que estamos propondo é a existência de um continuum de posições que ligam os adolescentes in aos adolescentes out. Melhor dizendo, sugerimos que agenciamento de uma adolescência in produz uma adolescência out. Conseqüentemente, ao localizarmos algum segmento juvenil como vulnerável corremos os riscos de focalizar a ação social como se apenas ali se encontrasse o déficit ou a negatividade.

Isto posto, podemos nos indagar agora o que se entende por cumprimento de medidas em meio aberto tendo em vista a insegurança generalizada, onde a cidade é sentida como uma imensa área de risco. Torna-se necessário, então, pensar em como abrir a cidade justamente quando as demandas dos cidadãos corroboram tanto o corte de despesas com políticas sociais quanto o aumento de custos com polícias, prisão ou proteção pessoal. Paradoxalmente, oscila-se entre o pedido de menos governo/mais governo, o que não raro se traduz em demandas por um Estado de bem-estar mínimo e um Estado penal máximo (WACQUANT, 1999).

No caso da violência juvenil, isto pode explicar em parte porque a população sequer indaga sobre o elevado ônus financeiro e social do aprisionamento de adolescentes, como refere este ex-interno:

Eu olhava pro lado, né, e as pessoas já me julgavam como ladrão, me colocavam já como um nada, embaixo da sombra da minhoca.

É raro que a população questione "os conflitos dos gestores públicos com a lei", no caso, o cumprimento do que é preconizado pelo Estatuto da Criança e do Adolescente em termos de acesso a políticas sociais e protetivas. Parecem não estranhar a subtração do direito à convivência familiar e comunitária. Este é o caso em análise, uma vez que a regionalização do sistema socioeducativo somente se implantou na jurisdição deste Juizado Regional após 13 anos de vigência do ECA e depois de 7 outras unidades construídas no interior do Estado, mesmo com a maior taxa de internação.

Tampouco as comunidades se mostram indignadas com o fato de que a execução das medidas em meio aberto 
continua judicializada ${ }^{4}$, sendo que apenas $16 \%$ dos jovens com medidas de Prestação de Serviços à Comunidade e em Liberdade Assistida estavam acompanhados pela equipe do Juizado em 2005. Ou seja, 84\% dos adolescentes infratores tinham a medida definida, mas não executada, alimentando a idéia de que a prática de delitos "não dá nada" e de que a única alternativa é mesmo "fechar", privá-los da liberdade. Além disto, o município tem um dos índices mais baixos de adolescentes com medidas em meio aberto em uma região que, por sua vez, apresenta o menor percentual de todo o estado $(0,23 \%$ do total de adolescentes na população).

Como isto concorre para o agravamento do perfil dos jovens infratores, nossa hipótese é de que tais circunstâncias podem explicar a elevada taxa de internação de adolescentes de São Leopoldo, a maior do Rio Grande do Sul. Ao mesmo tempo, fere o princípio do Estatuto que determina que a gravidade do ato infracional não justifica a internação, pois esta é a última medida e, como afirma o art. 122, em nenhuma hipótese será aplicada a internação, havendo outra medida adequada. Portanto, o juiz acaba aplicando a privação de liberdade pela inexistência de programas e serviços adequados em meio aberto; assim, o adolescente mais uma vez acaba sendo penalizado, isto é, punido pela omissão do poder público em cumprir aquilo que a lei lhe impõe.

Cabe ressaltar ainda outros sérios prejuízos da judicialização das medidas em meio aberto. Mesmo ocorrendo de forma precária, este atendimento acaba onerando o próprio Judiciário pela mobilização de seus funcionários em detrimento das funções tipicamente jurisdicionais. Também concorre para uma má imagem institucional dos operadores de Justiça ao responder política e publicamente pelo ônus de cumprir em condições precárias uma competência administrativa que legalmente não lhe pertence.

$\mathrm{Na}$ atenção ao adolescente infrator estabelece-se um "jogo de empurra-empurra" entre conselheiros tutelares, policiais, operadores de justiça e gestores públicos. Ou, entre família, município e Estado, como sugere esta fala da presidente da Fundação de Atendimento Sócio Educativo (FASE sucessora da FEBEM no Rio Grande do Sul), em entrevista à mídia regional:

Se o jovem voltar pra essa sua família e se sua família estiver em condições piores, mais empobrecidas, com mais boca para alimentar, sem chance de emprego e renda, ou trabalho e renda, encontrará condições inclusive pra ele reincidir, porque ele não vai ter outras alternativas lá fora. Esse jovem volta para o seu município, ele é cidadão daquela cidade, ele num instante está lá de volta, e ele volta. É jovem e a expectativa de vida é longa, ele vai ficar na sua cidade. Então, a sua cidade tem que voltar o olhar para a sua familia, capacitá-la para que ela resolva os seus problemas. Organize-se, tenha profissionalização, tenha chance de renda, e chance de educar e orientar seus filhos para conduzir de forma melhor. Porque, se um jovem está aqui dentro, a doença é da sociedade e daquela família.

Considerando que o Estatuto da Criança e do Adolescente é bastante claro ao definir que tais sujeitos devem ser considerados prioridade absoluta para a família, sociedade e Estado, torna-se difícil afirmar que se trata de uma "doença" que é da sociedade, mas o problema é do município ("ele vai ficar na sua cidade") e a saída é capacitar a família "para que ela resolva seus problemas" (o grifo é nosso).

O conjunto destas situações confirma a idéia de Agamben (2002), para quem o poder soberano resulta de uma articulação entre a norma e a exceção, sendo que o papel da norma é, sobretudo, instituir as condições políticas para que haja a exceção. Assim, todo excesso é autorizado e mantido sob a guarida do poder normatizador. Não se trata de fenômeno pré-político ou exterior à política, pois a exceção subsiste de forma protegida e em relação com a regra. Logo, tanto as vidas resguardadas como as vidas expostas fazem parte da vigência da norma por sua aplicação ou desaplicação.

Nestes termos, pode-se afirmar que a aplicação da medida socioeducativa não coloca o adolescente em conflito com a lei nem fora nem dentro do ordenamento, pois permanece referido e à mercê da lei, ou seja, no interior de normas que lhe conferem valor e significado. Isto é o que se pode observar na aplicação das medidas em meio aberto. De um lado, os operadores do sistema socioeducativo e os gestores municipais trabalham com estratégias limitadas no tempo, através de "operações de reposição" (CASTEL, 2004), como é o caso da concessão de bolsas-auxílio ou de empregos temporários. Por outro lado, buscam uma inserção pelo déficit, ao garantir, no máximo, atendimentos precarizados de saúde e educação, ou encaminhamento para empregos de baixa remuneração e valorização social. E mais grave, ainda, é o fato de que não raramente se reduz a prestação de serviços à comunidade feita por jovens de periferia em lugares e funções insalubres, como a faxina de banheiros públicos, enquanto aos adolescentes de maior poder aquisitivo é dado o privilégio de pagarem, com o dinheiro dos pais, uma cesta básica.

De qualquer maneira, chama a atenção o fato de que, no primeiro semestre de 2005, 61\% das medidas aplicadas em meio aberto eram de prestação de serviços à comunidade e em $28 \%$ dos casos ela foi definida por até dois meses, o que nos leva a indagar se é possível alguma proposta socioeducativa ser efetivada em tão curto espaço de tempo. Ao contrário, a inflexão maior da aplicação 
da medida parece estar relacionada ao que o adolescente fez, numa perspectiva meramente retributivo-punitiva, e não em razão do que ele necessita para sua recuperação ou para evitar a reincidência. A ênfase de abordagem estaria, então, no delito e não na adolescência.

Estas formas de operacionalização das medidas em meio aberto contrariam frontalmente as recomendações do Conselho Nacional dos Direitos da Criança e do Adolescente (CONANDA) de que os regimes socioeducativos devam garantir o acesso do adolescente às oportunidades de superação de sua condição de exclusão, bem como o acesso à formação de valores positivos de participação na vida social. Isto nos remete a concluir com Demo (1998) de que a inserção pode ser um modo elegante de exclusão pois, na melhor das hipóteses, focaliza ações assistencialistas, que deixam os adolescentes infratores empobrecidos ainda desfiliados e desqualificados.

Tais situações nos levam a propor que no imaginário social a adolescência pobre e infratora se define como um tipo peculiar de figura-limite, resultante da dificuldade de distinguir com clareza entre pertencimento e inclusão, entre o que está fora e o que está dentro, entre exceção e norma, tal como aponta Agamben (2002). Ou seja, o adolescente em conflito com a lei não pode ser incluído no todo ao qual pertence e não pode pertencer ao conjunto no qual está desde sempre incluído.

Tal inclusão sem pertencimento seria, então, indício de um fracasso no modelo socioeducativo preconizado pelo ECA? Estaríamos diante de sérios obstáculos de garantir a pretendida proteção integral e a inclusão destes adolescentes? Nossa hipótese é de que existe uma quase impossibilidade do sistema socioeducativo de fazer coincidir a inclusão com o pertencimento e isto não apenas por falhas institucionais. Isto porque se estabelece uma "relação de exceção" ou de "relação de bando", onde o adolescente que foi banido não é simplesmente posto fora da lei e a ela indiferente, mas é abandonado por ela, colocado em risco no limiar em que vida e direito, fora e dentro da cidade, se confundem. A lei a ele aplicada desaplica-se, mantém o jovem infrator em seu bando, abandonando-o fora de si. A porta aberta o inclui, excluindo-o e o exclui incluindo-o. O adolescente é, ao mesmo tempo, capturado e dispensado, tanto em meio fechado como em meio aberto. Portanto, trata-se de um "sobrante", que não tem lugar e talvez não seja integrável, o que equivale a dizer "sem utilidade social".

\section{Abrindo o meio e a discussão...}

Em síntese, este estudo sugere que a rejeição ao adolescente em conflito com a lei esteja relacionada ao fato de que seu ato infracional denuncia, como sugere Rassial (1999), uma ausência dos fundamentos das regras da vida social contemporânea. E nossa surdez a esse apelo seria, em parte, uma defesa narcísica social, ou seja, um escape ao confronto da miséria que o próprio sistema produz.

Por outro lado, propomos ser necessário descentrar a preocupação quanto aos chamados "adolescentes em vulnerabilidade social" (geralmente associados à juventude pobre) para o tema da vulnerabilidade das novas gerações, devido à sua incorporação radical de um estilo de vida sustentado em relações de consumo e na identificação com o dinheiro, em crescente processo de midiatização. Neste sentido, é necessário que os operadores do sistema socioeducativo levem em conta e priorizem ações capazes de problematizar a ghetificação das elites e das periferias na cidade contemporânea e do compartilhamento destes distintos segmentos sociais da espantosa capacidade de favorecer a morte da comunidade, como sugere Bauman (2004).

Propomos que um dos enfrentamentos necessários é o imaginário social, onde a adolescência pobre e infratora se define como um tipo peculiar de figura-limite, resultante da dificuldade de distinguir entre pertencimento e inclusão, entre o que está fora e o que está dentro, entre exceção e norma. Ficou evidente que a cultura do medo alimenta práticas retributivo-punitivas em relação aos jovens infratores e dificulta o processo de descentralização do sistema educativo, como a regionalização das unidades de internação e a aplicação de medidas em meio aberto. E que tampouco tais iniciativas garantem o direito à convivência familiar e comunitária dos adolescentes infratores, tampouco sua inclusão social.

$\mathrm{Na}$ medida em que a aplicação de medidas socioeducativas em meio aberto não consegue romper com 
a política de confinamento e acaba favorecendo estratégias de isolamento e imobilidade de jovens infratores, a maior condenação que parece imposta a eles é deixá-los entregues ao niilismo, no cruzamento entre uma matabilidade e uma insacrificabilidade (AGAMBEN, 2002), tanto fora do direito humano (pela impunidade da matança) quanto do divino (por que não goza da importância atribuída à vítima sacrificial, cuja morte carrega enorme significação para a comunidade, ao evocar proteção e salvação). Ou seja, a juventude empobrecida torna-se matável e insacrificável, um objeto privilegiado de violência devido a uma vida exposta e, ao mesmo tempo, sem importância, passível de ser sujeitada e golpeada.

Assim, como não lembrar da licitude das altas taxas de homicídio juvenil em nosso país, que provocam milhares de mortes que, via de regra, não são classificadas como violação de direitos ou sequer sacrilégio? Estaríamos diante de vidas que não merecem ser vividas? Os adolescentes brasileiros, à mercê da orgia dos bens de consumo, teriam se tornado eles próprios bens descartáveis? Teriam perdido a tal ponto a qualidade de bem jurídico que, tanto para si como para a sociedade, suas vidas não são mais reivindicadas?

Contudo, reiteramos que não se pode falar em falhas políticas quando os adolescentes se tornam vulneráveis ou torturáveis, dentro ou fora do sistema socioeducativo, pois a colocação de seus corpos em permanente risco é um fenômeno intrinsecamente político ${ }^{5}$. Quando a desconsideração com os desfavorecidos se justifica a tal ponto e o alheamento complacente fica legitimado, pergunta-se: quem deve se proteger de quem e do quê?

Ao final, chamamos a atenção para o fato que a redução nas liberdades dos excluídos nada acrescenta à liberdade dos livres. Sem solidariedade, nenhuma liberdade é segura. Afinal, como diria Ghandi, olho por olho e acabaremos todos cegos...

\section{Recebido em 17.10.2005. Aprovado em 23.11.2005.}

\section{Referênciass}

AGAMBEN, G. Homo Sacer: o poder soberano e a vida nua. Belo Horizonte: Editora da UFMG, 2002.

BAUMAN, Z. Globalização: as conseqüências humanas. Rio de Janeiro: Jorge Zahar Editor, 1999.

Comunidade: a busca por segurança no mundo atual. Rio de Janeiro: Jorge Zahar Editor. 2004.

BRANCHER, L. N. Semântica de exclusão. 2002. Disponível em <www.abmp.gov.br>. Acesso em 12 out. 2005.

BRASIL. Ministério da Justiça. Mapeamento Nacional da Situação do Atendimento de Adolescentes em Cumprimento de Medidas Socioeducativas. Brasília: IPEA/ SEDH/DCA, 2002.
CALliGARIS, C. Adolescência. São Paulo: Publifolha, 2000.

CASTEL, R. As transformações da questão social. In: WANDERLEY-BELFORE, M. et al. (Orgs.). Desigualdade e a questão social. 2. ed. São Paulo: EDUC, 2004, p. 235-264.

DEMO, P. Charme da exclusão social. Campinas: Autores Associados, 1998.

ECA-Estatuto da Criança e do Adolescente, Lei 8.069/90. Apresentação Siro Darlan. Rio de Janeiro: Ed. DP\&A, 2004, 159p.

DIÓGENES, G. Cartografias da cultura e da violência. São Paulo: Annablume, 1998.

FUNDAÇÃO DE ECONOMIA E ESTATÍSTICA. Pesquisa de Emprego e Desemprego da Região Metropolitana de Porto Alegre. Porto Alegre, 2003.

GLASSNER, B. Cultura do medo. São Paulo: Francis, 2003.

IBGE-Instituto Brasileiro de Geografia e Estatística. Pesquisa Nacional por Amostragem Domiciliar, 2001. Disponúvel em $<$.http://www.ibge.gov.br/home/estatistica/populacao/trabalho erendimento/default.shtm> Acesso em 12 abr. 2001.

OLIVEIRA, C. S. de Sobrevivendo no inferno: a violência juvenil na contemporaneidade. Porto Alegre: Sulina, 2001.

RASSIAL, J. Haveria uma psicopatologia das periferias. In: COSTA, A. et al. Adolescência e experiências de borda. Porto Alegre: Editora da UFRGS, 2004, p. 287-303.

RIO GRANDE DO SUL. Secretaria Estadual de Justiça e Segurança. Relatório 2003/2. Porto Alegre, 2003.

SARAIVA, L. G.; PEREIRA, G. S. Realidade da execução das medidas socioeducativas em meio aberto no estado do Rio Grande do Sul. Santo Ângelo: CEDEDICA, 2005.

UNICEF-Fundo das Nações Unidas para a Infância. Relatório “Custos e qualidade das medidas sócio-educativas". Brasília, 2002.

WACQUANT, L. Crime e castigo nos Estados Unidos: de Nixon a Clinton. Revista de Sociologia e Política, Curitiba, n. 13, p. 39-50, nov. 1999.

As Prisões da miséria. Tradução André Telles. Rio de Janeiro: Jorge Zahar Editores, 2001.

\section{Notas}

1 Todos os depoimentos, transcritos na íntegra, ao longo deste trabalho foram obtidos pelo grupo de discussão com adolescente em cumprimento de medida socioeducativa, conforme indicado na introdução, em São Leopoldo, 2004.

2 Abrangendo 35 municípios em 14 Comarcas nos municípios de Campo Bom, Dois Irmãos, Estância Velha, Esteio, Igrejinha, Montenegro, Novo Hamburgo, Parobé, Portão, São Leopoldo, São Sebastião do Caí, Sapiranga, Sapucaia do Sul e Taquara. Este Juizado Regional tem sede em Novo Hamburgo, que sedia ainda a unidade regional de privação de liberdade da FASE (Fundação de Atendimento SocioEducativo, sucessora da FEBEM no Rio Grande do Sul).

3 Estes dados foram obtidos com a Assessoria de Gestão e Informação, da Fundação de Atendimento SocioEducativo 
do Estado do Rio Grande do Sul (FASE), em 2004.

4 No estado, $41 \%$ das medidas de Liberdade Assistida e 58\% de Prestação de Serviços à Comunidade continuam inteiramente a cargo do Juizado (SARAIVA; PEREIRA, 2005)

5 Considerando que o custo mínimo per capita em unidades de privação de liberdade é de R $\$ 1.898$ (UNICEF, 2002), na época se podia estimar um gasto mensal não inferior a $\mathrm{R} \$ 129.000,00$ com a internação dos 68 adolescentes provenientes de São Leopoldo, o que supera em um mês a dotação orçamentária do município para o Conselho Municipal dos Direitos da Criança e do Adolescente para aquele ano. Tal cálculo demonstra que não se trata, evidentemente, de falta de recursos, mas de uma opção na gestão e no estabelecimento de prioridades. Se a soma anual destes custos de internação fosse destinada para políticas comunitárias junto a este segmento, que chega a 36.607 adolescentes, teríamos um possível investimento anual de R\$1.548.768,00. Não seria o caso, então, de haver uma inversão de prioridades?

\section{Carmen S. de Oliveira}

carmenoliveira@terra.com.br

\section{Maria Palma Wolff}

palmaw@unisinos.br

\section{Ronaldo Henn}

henn@unisinos.br

\section{Marta Conte}

martacon@portoweb.com.br

Universidade do Vale do Rio dos Sinos - Unisinos

Av. Unisinos, 950

Bairro Cristo Rei

São Leopoldo - Rio Grande do Sul

CEP: 93022-000 